\title{
OCORRÊNCIA DE SÍNDROME DA MÁ ABSORÇÃO DE ZINCO (Zn) EM BOVINOS DA RAÇA SIMENTAL
}

M.V. FERRARI ${ }^{1}$; A. FOLADOR ${ }^{2}$; F.L. RIBEIRO33 ${ }^{3}$ M.A. DA SILVA ${ }^{3}$; S.T.S. COLLODEL ${ }^{3}$

${ }^{1}$ Departamento de Medicina Veterinária. ${ }^{2}$ Curso de Pós-Graduação em Ciências Veterinárias. ${ }^{3}$ Curso de Medicina Veterinária, Setor de Ciências Agrárias, Universidade Federal do Paraná

A Síndrome da mal absorção de zinco caracteriza-se pela deficiência de absorção de zinco a nível intestinal e é atribuída a um defeito hereditário causado por um gene autossômico recessivo. A síndrome foi descrita em bovinos, machos e fêmeas, da raça holandesa em diversos países da Europa e caracteriza-se por lesões predominantemente de pele, tais como paraqueratose, pelos ásperos, secos e opacos, e escaras esbranquiçadas muito doloridas ao arrancamento, e, em alguns casos, lesões na boca e intestinos causadoras de salivação e diarréia constantes, que levam a um subdesenvolvimento corporal dos animais afetados. $O$ único tratamento eficaz para a Síndrome é o fornecimento oral continuado de zinco, o que leva ao desaparecimento das lesões em poucas semanas e o retorno ao desenvolvimento corporal. A interrupção no fornecimento de zinco causa o reaparecimento das lesões após uma a duas semanas, com os primeiros sinais clínicos observados nos pelos que se tornam ásperos e sem brilho. O objetivo do trabalho é relatar a ocorrência da referida síndrome em três bovinos da raça simental oriundos de criatório localizado na região sul do Paraná. Os três animais eram fêmeas e com parentesco direto, mãe e duas filhas, sendo estas irmãs inteiras oriundas de transferência de embriões colhidos e transferidos às receptoras na mesma data. Do total de 95 animais pertencentes ao rebanho, somente as três (3,16\%) apresentaram a síndrome. A progenitora tinha 4 anos de idade e apresentou lesões de pele na região do sacro, com paraqueratose localizada, alopecia, fezes constantemente fluidas e deformações nas unhas, caracterizadas por alterações de crescimento e firmeza da muralha e sola. As filhas tinham 14 meses de idade e apresentavam lesões de pele generalizadas e mais pronunciadas, com formação de escaras firmemente aderidas e muito doloridas ao arrancamento. As duas mostravam desenvolvimento corporal abaixo do esperado para a idade, lesões mais graves nas unhas com, inclusive, perda do estojo córneo e claudicação evidente. A fluidez excessiva das fezes e a má qualidade dos pelos era característica comum às duas novilhas e, conforme relato dos tratadores, os primeiros sinais clínicos apareceram após a desmama dos animais, com cerca de 8 meses de idade. O diagnóstico foi feito com base no histórico familiar, nos sinais clínicos e no tratamento efetuado. Uma das novilhas recebeu suplementação oral de óxido de zinco (0,5 g/dia) através de sonda enquanto a irmã e a mãe não receberam qualquer tratamento, com a finalidade de se comparar a evolução dos sinais clínicos nos três animais. A novilha que recebeu o suplemento de zinco mostrou melhorias nas características da pele e unhas a partir do primeiro mês do tratamento, com o desaparecimento completo das lesões ao fim do terceiro mês de tratamento, mostrando retorno ao desenvolvimento corporal normal para a idade, ganho de peso evidente e, inclusive, entrada em atividade sexual, com sinais de estro a cada 21 dias. A mãe e a irmã que não receberam a suplementação de zinco no mesmo período, mostraram agravamento das lesões de pele e unhas e continuaram com as fezes fluidas e a claudicação. Após 6 meses, o fornecimento de óxido de zinco foi descontinuado, ocorrendo o reaparecimento das lesões na novilha tratada, com início a partir da primeira semana e atingindo o ponto máximo após 4 meses da interrupção, com o reaparecimento de todos os sinais clínicos inicialmente verificados. Com base 
nestes dados, concluiu-se que as lesões apresentadas pelos animais eram decorrentes da síndrome de mal absorção de zinco, de vez que todo o rebanho recebia níveis adequados do microelemento através de arraçoamento e sal mineralizado e somente as três apresentaram as lesões descritas. 